\title{
BAHASA TAMSIL HADIS DALAM KITAB RIYADUSH SHALIHIN: KAJIAN BAB MENJAGA SUNNAH-SUNNAH NABI SAW
}

\author{
Zakiar \\ Pimpinan Pondok Pesantren Darul Qur'an Kerinci \\ email: zakiar@iainkerinci.ac.id
}

\begin{abstract}
This paper examines the hadiths of the hadith tradition in riyadush shalibin: the study of the guarding of the Sunnah of the Holy Prophet. The issues that are being studied are: What are the traditions of the Holy Prophet in the chapter to keep the Sunnah of the Holy Prophet in Riyadush Shalibin, how the quality and how the scholars understand it. This research is pure literature by using the method of criticism of hadith as a means of assessing the quality of the hadith. The maudu'i method and the textual and contextual interpretation techniques of the hadiths have ensured the quality is authentic, then understood. The approach used is normative and linguistic. The results of the study show that the qualities of the badith in badeeth in the book of riyadush shalibin: the study of the chapter keeping the sunnah-sunnah of the prophet saw is authentic, while from the point of understanding, the hadith that speaks is only the way the Prophet gave the teaching of targib and tarbib to Muslims all the time.
\end{abstract}

Keyword: : Tamsil Hadith, Riyadush Shalibin, Sunnah

\begin{abstract}
Abstrak: Tulisan ini mengkaji hadis-hadis tentang bahasa tamsil hadis dalam kitab riyadush shalihin: kajian bab menjaga sunnah-sunnah nabi saw. Pokok permasalahan yang dikaji adalah: Apa saja hadis nabi saw yang berbahasa tamsil dalam bab menjaga sunnah-sunnah nabi saw pada kitab Riyadush Shalibin, bagaimana kualitasnya dan bagaimana ulama memahaminya. Penelitian ini murni kepustakaan dengan menggunakan metode kritik hadis sebagai sarana menilai kualitas hadis. Metode maudu'i dan teknik interpretasi tekstual dan kontekstual hadishadis yang telah dipastikan kualitasnya sahih, selanjutnya dipahami. Adapun pendekatan yang digunakan adalah normatif dan kebahasaan. Hasil penelitian menunjukkan bahwa kualitas hadis yang berbahasa tamsil dalam kitab riyadush shalibin: kajian bab menjaga sunnah-sunnah nabi saw berstatus sahih, sedangkan dari sudut pemahaman, hadis yang berbahasa hanyalah cara Nabi saw memberikan pengajaran berupa targib dan tarbib kepada umat Islam sepanjang masa.
\end{abstract}

Kata Kunci: Bahasa Tamsil Hadits, Kitab Riyadush Shalihin, Sunnah Nabi 


\section{PENDAHULUAN}

Hadis didefinisikan oleh ulama sebagai segala sesuatu yang dinisbahkan kepada nabi Muhammad saw. berupa perkataan, perbuatan, ketetapan, serta sifat fisik maupun fsikis, baik sebelum diutus menjadi nabi maupun setelah diutus. ${ }^{1}$ Pengertian ini berbeda dengan pengertian yang dikemukan oleh ulama ushul fiqh, hadis didefenisikan, semua yang dinisbatkan kepada nabi saw. berupa ketentuan-ketentuan yang berkenaan dengan hukum.

Definisi ini sejalan dengan pemahaman ulama tafsir terhadap ayat-ayat al-Qur'an yang memerintahkan untuk ta'at kepada Nabi saw. Perintah Allah swt. untuk menta'ati Rasulullah saw., tampil dalam dua bentuk redaksi berikut ini:

Pertama, al-Qur'an, Surat al-Imran/3: 32

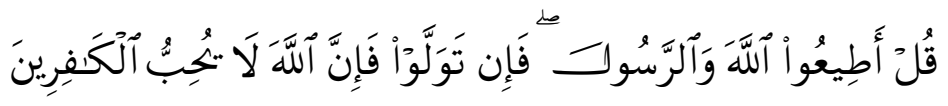

Terjemahnya: Katakanlah! "Ta'atilah Allah dan Rasul-Nya; jika kamu berpaling, Maka Sesungguhnya Allah tidak menyukai orang-orang kafir". ${ }^{2}$

Kedua, al-Qur'an, Surat al-Nisa'/4: 59

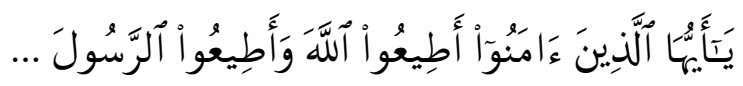

Terjemahnya: Hai orang-orang yang beriman, taatilah Allah dan taatilah Rasul (Nya)...

Pada ayat pertama perintah ta'at kepada rasulullah saw. dilaksanakan sekaligus menjalankan semua yang diperintahkan Allah swt, kerena apa yang diperintahkan rasul saw, sesunggunya adalah juga yang diperintahkan Allah swt. demikian maksud dari penggunaan satu kata perintah "ta'atilah" tersebut. berbeda halnya dengan ayat yang kedua, kosa kata perintah "ta’tilah" diulang dua kali, pertama perintah menta'ati Allah swt. dan yang kedua perintah menta'ati rasulullah saw. Secara khusus, walaupun yang diperintahkan oleh rasulullah saw. tidak tersebut secara tegas oleh Allah swt. dalam al-Qur'an.

Jika rujukan utama dalam menta'ati Allah swt, adalah al-Qur'an dan hadis, maka rujukan utama dalam menta'ati rasulullah saw, adalah hadis nabi saw, itu sendiri. Dengan kata

1 Pengertian hadis seperti ini dapat dilihat, Al-Khatib, Muhammad 'Ajjaj, al-Sunnah Qabl al-Tadwin (Bairut: Dar al-fikr, 1997), hal. 18.

كل ما أثر عن النبي ثلئه من قول، أو فعل، أو تقرير، أو صفة خلقية أو خلقية، أو سبرة، سواء كان ذلك قبل البعثة أو بعدها.

Pengertian hadis, seperti ini, menurut mubaddisin merupakan muradif dari sunnah.

${ }^{2}$ Departemen Agama RI, Al-Qur'an dan terjemahnya (Surabaya: Fajar Mulia, 2009), hal. 54

${ }^{3}$ Ibid, hal. 87. 
lain bahwa al-Qur'an dan Hadis Nabi saw. merupakan satu kesatuan yang tidak dapat dipisahkan dalam menjalankan fungsinya sebagai petunjuk bagi manusia yang sekaligus sebagai syarat keimanan.

Sebagai sumber utama ajaran Islam, baik al-Qur'an maupun Hadis, hadir dengan petunjuk, umumnya, bersifat global, sedikit ditemukan petunjuk-petunjuknya yang rinci. Jika perincian dan penjelasan petunjuk al-Qur'an dilakukan oleh Nabi saw. sekaligus sebagai salah satu fungsi kenabiannya, maka penjelasan terhadap hadis nabi saw. rujukannya diarahkan pada orang-orang yang mendengarkan dan atau melihat dan mendapatkan penjelasan dari nabi saw, dalam hal ini adalah para sahabat, ${ }^{4}$ dan juga para pewarisnya.

Hadis nabi saw., sebagai petunjuk, hadir dalam bentuk ucapan, tindakan, ketetapan, sifat zahir dan batin, serta keinginan. Petunjuknya yang berbentuk ucapan tampil pula dengan beberapa tipe antara lain, Jawami' al-Kalim (ungkapan yang singkat, namun padat makna), ${ }^{5}$ tamsil (perumpamaan) ${ }^{6}$, dan ram $2 i$ (bahasa simbolik) ${ }^{7}$.

Konpleknya persoalan di bidang petunjuk hadis ini, meniscayakan perlunya memahami hadis-hadis rasulullah saw. tersebut agar petunjuk-petunjuk tersebut dapat dijadikan acuan dalam kehidupan keberagamaan.

Pemahaman terhadap kandungan petunjuk al-Qur'an (ayat-ayatnya), disebut Tafsir. ${ }^{8}$ Orang yang melakukan kegiatan tafsir disebut dengan Mufassir, Para mufassir menggunakan empat metode dalam menafsirkan ayat-ayat Al-Qur'an, yaitu metode tablili, ijmali, muqaran dan maudu'i.

Pemahaman terhadap kandungan petunjuk Hadis, atau segala sesuatu yang disandarkan kepada Nabi Muhammad saw. berupa perkataan, perbuatan, ketetapan, bahkan sifatnya, disebut dengan, syarah. Para mubaddisin (sebutan untuk ulama hadis) dalam menjelaskan makna

${ }^{4}$ Sahabat adalah orang yang hidup semasa dengan nabi, beriman kepadanya, dan meninggal dalam Islam.

5 Pernyataan nabi saw. Berkenaan dengan itu adalah بعثت بجوامع الكلم , lihat Muslim bin al-Hajjaj (selanjutnya ditulis Muslim), Shahih Muslim, juz. 1 (Beirut: Dar. Ihya' al-Turas al-‘Araby, t.th), hal. 371.

${ }_{6}$ Ungkapan rasulullah saw. Yang berbentuk perumpamaan ditemukan pada ungkapan yang beragam, diantaranya, إن المؤمن للمؤمن كالبنيان يشد بعضه بعضا , orang mukmindengan orang mukmin lainnya ibarat satu bangunan, satu bagian memperkuat bagian yang lain, lihat Muhammad bin Isma'il al-Bukhari (selanjutnya ditulis Bukhari), Sahih Bukhari, Juz. 1 (Beirut: Dar. Ibn. Kasir, 1987), hal. 182.

7 Ungkapan dalam bentuk simbolik, selain dalam al-Qur'an ditemukan juga dalam hadis Nabi saw.

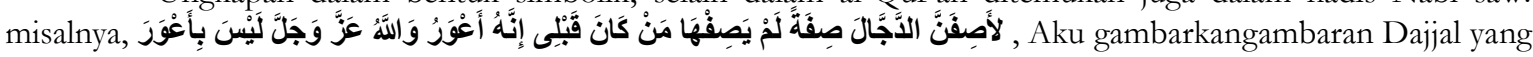
tidak pernah digambarkan oleh para nabi sebelumnya, Dajjal itu Buta sebelah matanya, dan Allah swt. Tidak buta sebelah matanya. Buta mata adalah bahasa simbolik. Lihat Ahmad bin Hambal, Musnad Ahmad, Juz. 4 (Mesir: Wazir al-auqaf, t. Th), hal. 109.

${ }^{8}$ Secara bahasa, Tafsir berasal dari bahasa Arab, فسر, yang berarti, البيان, Penjelasan. Sedangkan menurut istilah: Tafsir adalah suatu ilmu yang digunakan untuk memahami Kitab Allah SWT. Yang diturunkan-Nya kepada nabi Muhammad saw. Penjelasan makna-maknanya, serta menarik kesimpulan-kesimpulan hukum dan hikmah-hikmahnya. Lihat, Munawwir, AW, Kamus al-Munawwir Arab-Indonesia Terlengkap (Yogyakarta: Pustaka Progressif, 2002), hal. 1055, dan al-Suyuti, al-Itqan fii Ulum al-Qur'an,Juz. II (t.t: t.p, t.th), hal.174. 
(syarb) hadis juga menggunakan, mengadopsi, keempat metode yang digunakan para mufassir tersebut dalam memahami hadis-hadis Rasulullah saw. empat metode dimaksud adalah: a) metode Tablili; b) metode Ijmali; c) metode Muqaran; d) metode Maudu'iy

Dalam penelitian yang berjudul Bahasa Tamsil Hadis Nabi saw: Kajian Kitab Riyadush Shalihin ini, peneliti menggambarkan metode interpretasi (syarb) maudu'iy untuk memahami hadis Rasulullah saw. Metode ini, seperti disebut di atas merupakan sebuah metode "serapan" dari metode yang dikembangkan para mufassir dalam menafsirkan Al-Qur'an, ${ }^{9}$ Langkah-langkah atau cara kerja dalam tafsir maudu'iy adalah sebagai berikut: a. memilih dan menetapkan tema yang akan diangkat; b. melacak dan menghimpun ayat-ayat yang berkaitan dengan tema yang telah ditetapkan; c. menyusun ayat-ayat tersebut menurut kronologi masa turunnya, disertai dengan sabab nu₹ul-nya; d. mengetahui munasabah (korelasi) ayat-ayat tersebut dalam surahnya masing-masing; e. menyusun tema bahasan dalam kerangka yang pas, sistematis, sempurna, dan utuh; f. melengkapi pembahasan dan uraian dengan hadis bila dipandang perlu sehingga pembahasan semakin sempurna dan semakin jelas; dan g. mempelajari ayat-ayat tersebut secara tematik dan menyeluruh dengan cara menghimpun ayat-ayat yang mengandung pengertian serupa, mengkompromikan ayat-ayat yang 'am dan khas, mutlaq dan muqayyad, mensingkronkan ayat-ayat yang lahirnya kontradiktif, menjelaskan ayat-ayat yang nasikh dan mansukh, sehingga semua ayat bertemu pada titik sentral, tanpa perbedaan dan kontradiksi atau tindakan pemaksaan terhadap sebagian ayat kepada makna-maknanya yang sebenarnya yang tidak tepat.

Langkah-langkah yang disusun oleh para mufassir tersebut dengan beberapa penyesuaian digunakan pula oleh Mubaddisin untuk memahami hadis nabi saw. dikatakan demikian karena, para ilmuan tafsirlah yang pertama kali mengembangkan metode ini dalam memahami (menafsirkan) Al-Qur'an. Dan untuk konteks ke-Indonesia-an, pendekatan tafsir metode ini secara akademis diperkenalkan oleh Quraish Shihab. ${ }^{10}$

Sedangkan dalam kajian hadis maudu'i di Indonesia, secara teoretis dan praktis, kajian ini telah dilakukan oleh banyak pengkaji hadis, diantaranya; Abdul Mustaqim, dan Arifuddin Ahmad, penulis sebutkan demikian berdasarkan pada karya-karyanya yang telah dipublikasikan oleh kedua orang tersebut. Abdul Mustaqim, Paradigma Integrasi-Interkoneksi dalam Memahami Hadis, cetakan I buku ini dilaksanakan oleh penerbit Teras di Yogyakarta tahun 2009, Arifuddin Ahmad, Metode Tematik dalam Pengkajian Hadis, yang diterbitkan di Makassar oleh Universitas Islam Negeri Alauddin, tahun 2007.

${ }^{9}$ M. Quraish Shihab, Membumikan al-Qur'an (Bandung: Mizan, 1992), hal. 114. 206.

${ }^{10}$ Komaruddin Hidayat, Memahami Bahasa Agama Sebuab Kajian Hermeneutika (Bandung: Mizan, 2011), hal. 
Kajian hadis maudu'i, sebagai salah satu metode memahami hadis rasulullah saw. sangat menarik dijadikan pilihan dalam pengembangan keilmuan, karena kajian ini dapat diintegrasikan kepada berbagai disiplin ilmu. Selain itu dengan menerapkan metode ini, para pengkaji atau peneliti dapat memahami petunjuk hadis rasulullah saw. berkaitan dengan berbagai pembahasan keilmuan dan keislaman, Pada kapasitas inilah, penelitian ini diharapkan manfaatnya, serta beberapa manfaat teoretis dan praktis.

Kajian hadis di institusi pendidikan Islam memilih bentuk kajian hadis maudu'i, hal ini diketahui dengan nama-nama kajian hadis yang tersebar di beberapa jurusan atau program studi yang ada di institusi perguruan tingggi Islam di Indonesia, di Jurusan syari'ah kajian hadis disebut, Hadis Ahkam, di Tarbiyah, Hadis Tarbawi, di Dakwah, Hadis Dakwah dan seterusnya sesuai jurusan yang terdapat di berbagai institusi Pendidikan Islam masing-masing. Sedangkan salah satu kitab hadis yang menjadi rujukan untuk semua jurusan dan program studi dalam kajian hadis adalah kitab hadis Riyadhush Shalibin, atas dasar inilah pula, maka peneliti memilih Riyadhush Shalibin menjadi buku yang dikaji dalam penelitian ini, yang kajiannya difokuskan pada pemahaman bahasa tamsil hadis Nabi saw.

Bertitik tolak dari persoalan pada latar belakang tersebut di atas, permasalahan pokok penelitian ini adalah apa saja dan atau bagaimana bahasa tamsil hadis nabi saw, dipahami. Dari permasalahan pokok ini, dijabarkan pada beberapa masalah berikut: 1) apa saja hadis nabi saw. yang berbahasa tamsil dalam Bab menjaga sunnah-sunnah Nabi saw. pada kitab Riyadush Shalibin?; 2) bagaimana kualitas hadis nabi saw. yang berbahasa tamsil dalam Bab menjaga sunnah-sunnah Nabi saw. pada kitab Riyadush Shalibin tersebut?; dan 3) bagaimana ulama hadis memahami hadis nabi saw. yang berbahasa tamsil dalam bab menjaga sunnah-sunnah Nabi saw. pada kitab Riyadush Shalibin tersebut?

\section{METODE}

Penelitian ini dari segi jenisnya termasuk penelitian kepustakaan (library research), yaitu penelitian yang dilakukan melalui riset terhadap berbagai literatur (pustaka) yang berkaitan dengan tema penelitian, Bahasa Tamsil hadis Nabi saw. Pada kitab Riyadhush Shalihin. Sedangkan dari segi analisis data yang dilakukan, penelitian ini termasuk dalam kategori penelitian analitis kritis. ${ }^{11}$ Sedangkan dari segi manfaatnya, penelitian ini termasuk pada kategori penelitian murni (pure research), yakni penelitian yang diarahkan untuk pengembangan

11 Jujun Suriasumantri, "Penelitian Ilmiah, Kefilsafatan dan Keagamaan: Mencari Paradigma Kebersamaan", dalam Mastuhu (dkk), Tradisi Penelitian Agama Islam, (Bandung: Nuansa, 1998), h. 44. 
ilmu pengetahuan. Pengembangan yang dimaksud adalah pengembangan dalam salah satu metode pensyarahan hadis, yakni metode tematik atau maudu $\%$.

Menurut Noeng Muhadjir, penelitian ini adalah model studi pustaka atau teks yang seluruh substansinya memerlukan olahan filosofik atau teoritik yang terkait dengan nilai-nilai (values). ${ }^{12}$ Dalam hal ini, kajian hadis ini diarahkan pada aspek teoretis dan praktis. Selanjutnya mengingat fokus kajian ini teori dan langkah-langkah praktis memahami hadis Nabi saw, maka penelitian ini tentunya bersifat kualitatif. Seperti yang diungkap Moleong, bahwa di antara urgensi penerapan penelitian kualitatif adalah untuk pengkajian secara mendalam yang berupaya menemukan perspektif baru tentang hal-hal yang sudah diketahui. ${ }^{13}$ Dalam hal ini, kajian diarahkan pada pemahaman hadis sebagai nilai-nilai ajaran Islam dalam kehidupan dengan menggunakan metode pemahaman hadis secara maudu'i.

Sumber-sumber data penelitian adalah kitab-kitab (buku-buku), hasil-hasil penelitian, artikel-artikel ilmiah dan sumber-sumber tertulis lainnya, temasuk sumber-sumber yang berasal dari buku elektronik. Secara umum sumber data penelitian ini terdiri dari sumber data primer dan sekunder. Data primer penelitian ini adalah hadis Nabi yang berbahasa tamsil dari Kitab Hadis Riyadhush Shalihin.

Adapun data sekundernya bersumber dari kitab-kitab syarb hadis dan buku-buku ulumul Hadis. Selain itu digunakan pula buku-buku yang berkaitan dengan konteks penelitian, seperti buku-buku Ulumul Qur'an serta buku tafsir maudu'i, buku-buku ini digunakan karena, kajian maudu’i merupakan kajian yang tergolong baru pada kajian hadis atau merupakan kajian serapan dari ilmu tafsir.

Jurnal, dan artikel serta tulisan yang dipublikasikan pada media cetak, yang berkenaan dengan kajian yang diteliti, jika ditemukan sepanjang penelitian ini dilakukan juga dijadikan sebagai rujukan sekunder penelitian ini.

\section{HASIL PENELITIAN DAN PEMBAHASAN}

\section{Hasil Penelitian}

Takhrij Hadis Bahasa Tamsil Tentang Menjaga Sunnah-Sunnah Nabi SAW

Takhrij al-hadis yang dimaksudkan di sini adalah kumpulan hadis yang memuat bahasa tamsil yang terdapat dalam bab menjaga sunnah-sunnah nabi saw. pada kitab riyadus shalihin

${ }^{12}$ Lihat Noeng Muhadjir, Metodologi Penelitian Kualitatif, (Yogyakarta: Rake Sarasin, 1998), h. 296-297.

${ }^{13}$ Lihat uraian Lexy J. Moleong, Metodologi Penelitian Kualitatif, (Bandung: Remaja Rosdakarya, 2008), h. 7. 
telah ditelusuri dari berbagai kitab hadis yang enam sebagai kitab standar takhrij hadis yang telah disebutkan di atas.

Hadis-hadis yang ditakhrij dengan metode takhrij bi al-lafz. dilakukan dengan bantuan Maktabah Syamilab dan al-Mujam Mufahrasy li alfaz al-Hadis dan metode takhrij bi al-ma'na dilaksanakan dengan menggunakan petunjuk kitab Miftah Kunuz al-Sunnah, kedua kitab yang disebut terakhir disusun oleh A. j. Wensinck dan diterjemahkan oleh Fu'ad Abd. al-Baki.

Hadis tentang menjaga sunnah-sunnah nabi saw. pada kitab riyadus shalihin berjumlah 12 hadis, sedangkan hadis tentang menjaga sunnah-sunnah nabi saw. dalam kitab riyadus shalihin yang menggunakan bahasa tamsil dengan lafal "Mistlu" yang berasal dari kosa kata fi'il " ma-sta-la" ditemukan dua hadis. Dua hadis inilah selanjutnya dilakukan takhrij, dengan melakukan penelusurannya pada kitab standar yang telah ditetapkan di atas.

Adapun dua teks hadis yang dimaksud adalah:

a) Hadis pertama

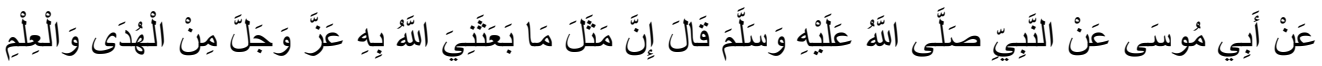

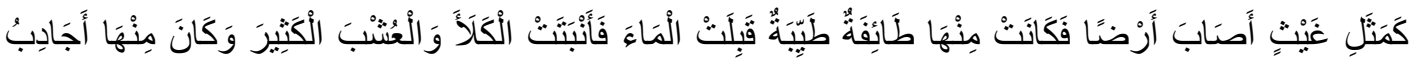

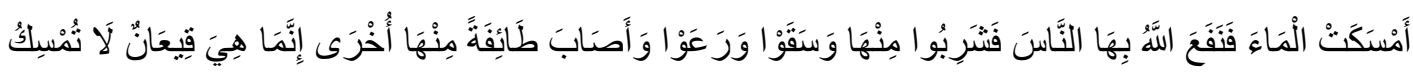

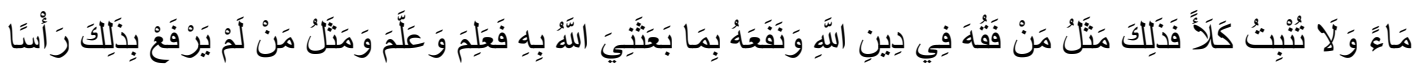

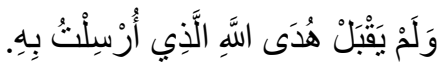

Artinya:

Abu Musa menerima dari Nabi saw. beliau bersabda: "Perumpamaan agama yang aku diutus Allah swt. dengannya, yaitu berupa petunjuk dan ilmu ialah bagaikan hujan yang jatuh ke bumi. Diantaranya ada yang jatuh ke tanah subur yang dapat menyerap air, maka tumbuhlah padang rumput yang subur. Diantaranya pula ada yang jatuh ke tanah keras sehingga air tergenang karenanya. Lalu air itu dimanfaatkan orang banyak untuk minum, menyiram kebun dan beternak. Dan ada pula yang jatuh ke tanah tandus, tidak menggenangkan air dan tidak pula menumbuhkan tumbuh-tumbuhan. Seperti itulah perumpamaan orang yang mempelajari agama Allah dan mengambil manfaat dari padanya, belajar dan mengajarkan, dan perumpamaan orang yang tidak mau tahu dan tidak menerima petunjuk Allah yang aku di utus dengannya. ${ }^{14}$

b) Hadis kedua

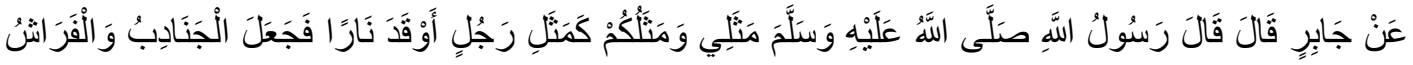

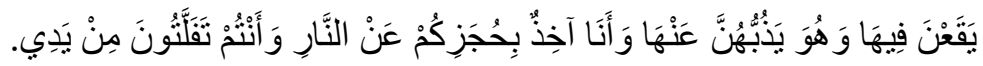

${ }^{14} \mathrm{Abu}$ Zakaria Yahya bin Syaraf al-Nawawi (selanjutnya ditulis Nawawi), Riyadhu al-Shalihin, terj. Jilid 1 (Jakarta: Pustaka Amani, 1999), h. 184. Hadis No. 7 
Artinya:

Jabir ra. berkata; Rasulullah saw. bersabda: Perumpamaanku dengan kamu sekalian ialah bagaikan seorang yang menyalakan api. Maka serangga-serangga beterbangan menjatuhkan diri ke dalam api itu. Orang tersebut berusaha menarik mereka dengan api dan mereka berusaha mengalahkannya. Dan aku, telah mencegah kamu semua agar tidak jatuh ke api, tetapi kamu meloloskan diri dari tanganku. ${ }^{15}$

\section{Takbrij Hadis pertama}

a) Lafal (kosa kata) yang dipilih untuk menjadi acuan takbrij al-hadis bagi hadis menjaga sunnah-sunnah nabi saw, yaitu lafal hadis yang menggunakan prase "inna matsala maa ba'atsani (إنَّ مَتَكَ مَا بَََتَنَيَ)". Pemilihan kosa kata untuk pencarian ini ditentukan dari teks hadis yang lengkap yang terdapat pada kitab yang diteliti, Riyadus Shalihin.

b) Setelah dilakukan penelusuran hadis ini pada enam kitab hadis (kutub sittah), hadis pertama berkenaan dengan menjaga sunnah-sunnah nabi saw. Ini ditemukan pada dua kitab hadis, yakni:

1) Shahih Bukhari

Pada kitab shahih Bukhari Juz I, hadis yang ditakhrij ini ditemukan satu riwayat pada

kitab Ilmu (Kitab III) bab (20) keutamaan orang yang berilmu dan mengajarkan ilmu

(فضل من علم و علم) hadis no. 79.

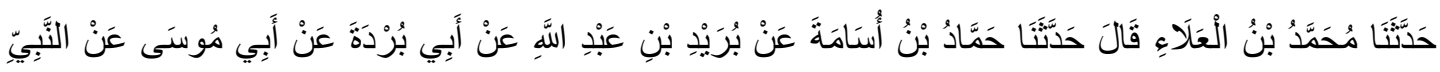

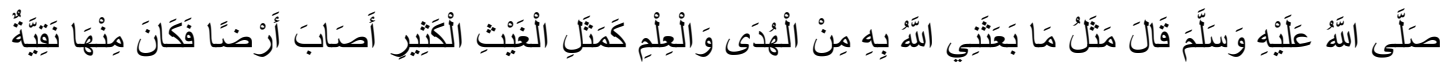

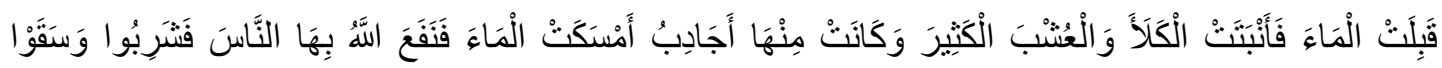

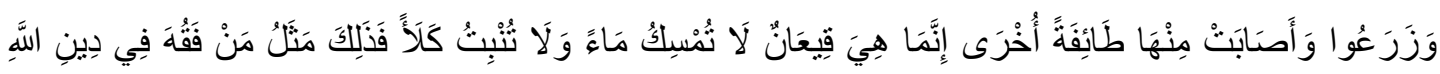

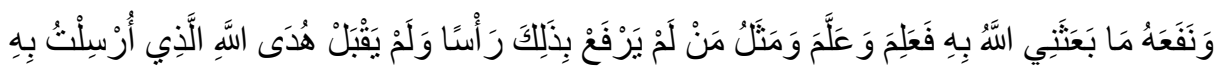

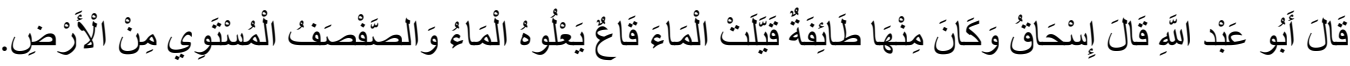

Artinya:

Telah menceritakan kepada kami Muhammad bin Al 'Ala' berkata, telah menceritakan kepada kami Hammad bin Usamah dari Buraid bin Abdullah dari Abu Burdah dari Abu Musa dari Nabi saw. beliau bersabda: "Perumpamaan petunjuk dan ilmu yang Allah mengutusku dengan membawanya adalah seperti hujan yang lebat yang turun mengenai tanah. Diantara tanah itu ada jenis yang dapat menyerap air sehingga dapat menumbuhkan tumbuh-tumbuhan dan rerumputan yang banyak. Dan di antaranya ada tanah yang keras lalu menahan air (tergenang) sehingga dapat diminum oleh manusia, memberi minum hewan ternak dan untuk menyiram tanaman. Dan yang lain ada permukaan tanah yang berbentuk lembah yang tidak dapat menahan air dan juga tidak dapat menumbuhkan tanaman. perumpamaan itu adalah seperti orang yang faham agama Allah dan dapat memanfa'atkan apa yang aku

${ }^{15}$ Ibid, h. 185 . Hadis no. 8. 
diutus dengannya, dia mempelajarinya dan mengajarkannya, dan juga perumpamaan orang yang tidak dapat mengangkat derajat dan tidak menerima hidayah Allah dengan apa yang aku diutus dengannya". Berkata Abu Abdullah; Ishaq berkata: "Dan diantara jenis tanah itu ada yang berbentuk lembah yang dapat menampung air hingga penuh dan diantaranya ada padang sahara yang datar".

2) Shahih Muslim

Pada kitab shahih Muslim Juz IV, hadis ini ditemukan satu riwayat pada kitab (43) keutamaan (الفضائل) bab (V) keutamaan umat nabi Muhammad saw. yang berilmu dan mendapatkan hidayah (باب بيان مثل ما بعث النبي صلى الله عليه و سلم من الهدى والعلم) hadis no. 1787 ,

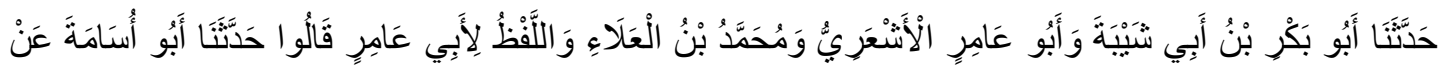

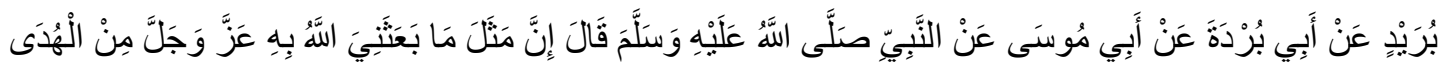

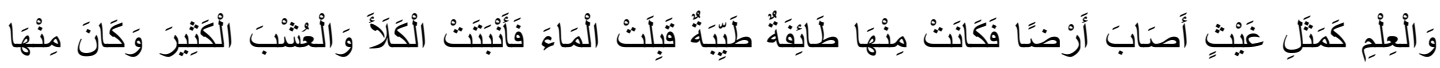

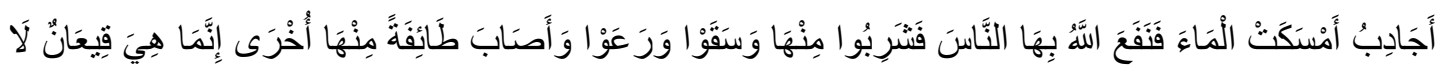

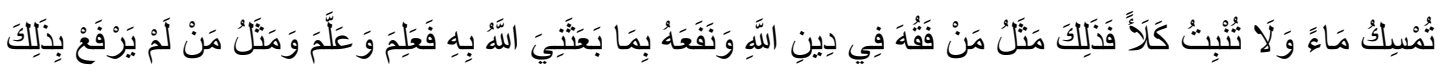

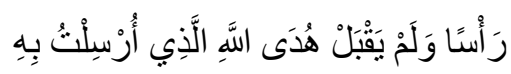

Artinya:

Telah menceritakan kepada kami Abu Bakr bin Abu Syaibah dan Abu 'Amir Al Asy'ari serta Muhammad bin Al 'Allaa lafazh ini milik Abu Amir mereka berkata; Telah menceritakan kepada kami Abu Usamah dari Buraid dari Abu Burdah dari Abu Musa dari Nabi saw. beliau bersabda: "Perumpamaan agama yang aku diutus Allah 'azza wajalla dengannya, yaitu berupa petunjuk dan ilmu ialah bagaikan hujan yang jatuh ke bumi. Diantaranya ada yang jatuh ke tanah subur yang dapat menyerap air, maka tumbuhlah padang rumput yang subur. Diantaranya pula ada yang jatuh ke tanah keras sehingga air tergenang karenanya. Lalu air itu dimanfaatkan orang banyak untuk minum, menyiram kebun dan beternak. Dan ada pula yang jatuh ke tanah tandus, tidak menggenangkan air dan tidak pula menumbuhkan tumbuh-tumbuhan. Seperti itulah perumpamaan orang yang mempelajari agama Allah dan mengambil manfaat dari padanya, belajar dan mengajarkan, dan perumpamaan orang yang tidak mau tahu dan tidak menerima petunjuk Allah yang aku di utus dengannya."

Terdapat perbedaan periwayat hadis antara jalur imam Bukhari dan jalur imam Muslim. Pada jalur Imam Bukhari para periwayatnya adalah; Muhammad bin Al 'Ala', Hammad bin Usamah, Buraid bin Abdullah, Abu Burdah dan Abu Musa ra. Sedangkan dari jalur Imam Muslim para periwayatnya adalah; Abu Bakr bin Abu Syaibah dan Abu 'Amir Al Asy'ari serta Muhammad bin Al 'Allaa, Abu Usamah, Buraid, Abu Burdah dan Abu Musa ra. 
Dari sini diketahui bahwa Imam muslim menerima hadis ini dari tiga orang guru yang setingkat dengan guru imam Bukhari yang bernama Muhammad bin 'Ala', pada jalur ini sanad yang dimiliki oleh Imam Muslim sama dengan sanad Imam Bukhari. Dan Imam Muslim meriwayatkan sendiri hadis ini dari dua orang guru lain yakni; Dari Gurunya Abu Bakar bin Abu Syaibah dan Abu 'Amir al-Asy'ariy.

Agar mudah melihat perbedaan tersebut di atas berikut ini ditampilkan jalur sanad Imam Bukhari dan Imam Muslim ke dalam tabel berikut:

\begin{tabular}{|c|c|c|c|}
\hline Sanad Imam Bukhari & \multicolumn{3}{|c|}{ Sanad Imam Muslim } \\
\hline Nabi saw. & \multicolumn{3}{|c|}{ Nabj saw } \\
\hline Abu Musa ra & \multicolumn{3}{|c|}{ Abu Musa ra } \\
\hline Abu Burdah & \multicolumn{3}{|c|}{ Abu Burdah } \\
\hline Buraid bin Abdullah & \multicolumn{3}{|c|}{ Buraid bin Abdullah } \\
\hline Hammad bin Usamah & \multicolumn{3}{|c|}{ Hammad bin Usamah } \\
\hline Muhammad bin al-'Ala' & $\begin{array}{l}\text { Muhammad } \\
\text { bin al-'Ala' }\end{array}$ & $\begin{array}{c}\text { Abu 'Amir al- } \\
\text { 'As'ariy }\end{array}$ & $\begin{array}{c}\text { Abu Bakar bin Abu } \\
\text { Syaibah }\end{array}$ \\
\hline
\end{tabular}

Perbedaan yang seperti ini tidak mempengaruhi kualitas suatu hadis dalam artian penurunan statusnya tetapi dapat meningkatkan statusnya dengan adanya tawabi' (pembanding diperingkat selain sahabat nabi saw).

Selain perbedaan dari tinjauan sanad, matan atau teks hadis riwayat imam Bukhari dan Imam Muslim juga memiliki perbedaan lafal pada beberapa kosa kata berikut ini,

\begin{tabular}{|c|c|}
\hline Teks Riwayat Imam Bukhari & Teks Riwayat Imam Muslim \\
\hline 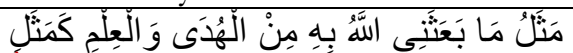 & 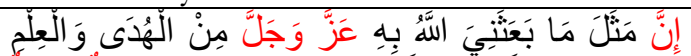 \\
\hline 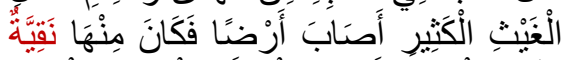 & 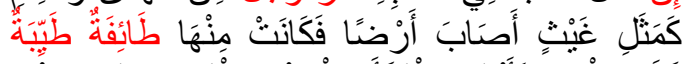 \\
\hline 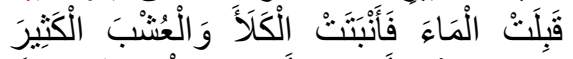 & 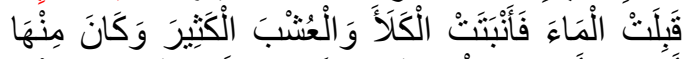 \\
\hline 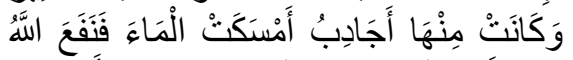 & 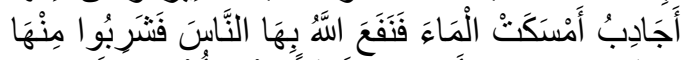 \\
\hline 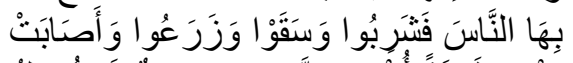 & 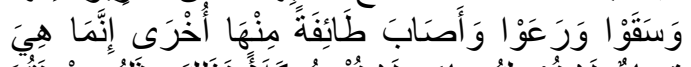 \\
\hline 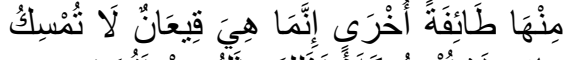 & 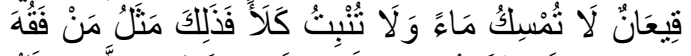 \\
\hline 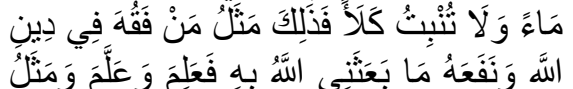 & 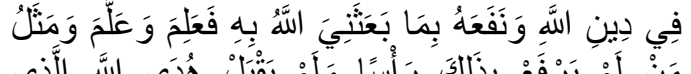 \\
\hline 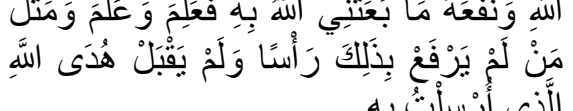 & يقبَل هدى السهِ الِِي \\
\hline
\end{tabular}


Perbedaan seperti ini, tidak merusak konten hadis. Hal ini disebabkan oleh periwayatan dengan makna (pemahaman periwayat). ${ }^{16}$ Adapun Teks (matan) hadis yang dipilih oleh penulis kitab Riyadus Shalihin adalah teks yang terdapat dalam shahih Muslim.

\section{Takbrij Hadis kedua}

Lafal (kosa kata) yang dipilih untuk menjadi acuan takhrij al-hadis bagi hadis menjaga sunnah-sunnah nabi saw pada bagian ini adalah: lafal hadis yang menggunakan prase “anqada naaran (اوقد نار)". Kosa kata ini dipilih karena dari beberapa kosa kata yang terdapat pada hadis kedua ini, kosa kata inilah yang mengantarkan peneliti menemukan keberadaan hadis.

Hadis ini dilakukan penelusurannya pada enam kitab hadis sebagai kitab standar yang telah ditetapkan di awal penelitian. Maka, peneliti menemukan hanya satu riwayat hadis ini pada kitab shahih Muslim Juz IV saja, yakni hadis no. 2285 pada kitab (43) keutamaan bab (VI) kecintaan Nabi saw. kepada ummatnya dan mengingatkan mereka agar terhindar dari marabahaya (باب شفقته صلى الله عليه و سلم على أمته ومبالغته في تحذير هم مما يضر هم). Teks hadis yang dimaksud adalah, berikut ini:

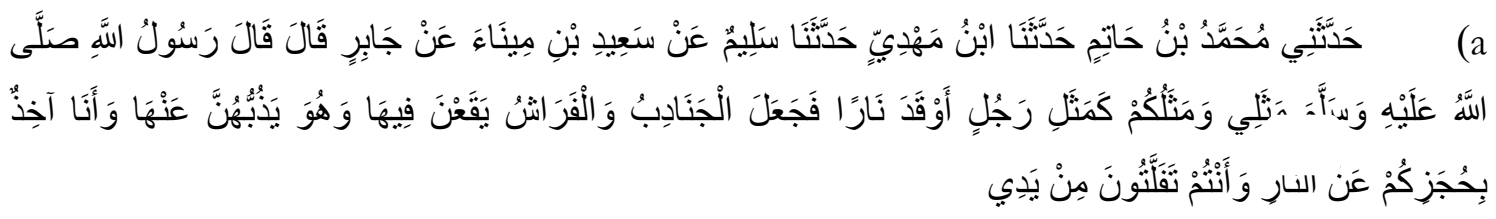

Artinya:

Telah menceritakan kepadaku Muhammad bin Hatim Telah menceritakan kepada kami Ibnu Mahdi Telah menceritakan kepada kami Salim dari Sa'id bin Mina dari Jabir ra. dia berkata; Rasulullah saw. bersabda: "Perumpamaanku dengan kamu sekalian ialah bagaikan seorang yang menyalakan api. Maka serangga-serangga beterbangan menjatuhkan diri ke dalam api itu. Orang tersebut berusaha menarik mereka dengan api dan mereka berusaha mengalahkannya. Dan aku, telah mencegah kamu semua agar tidak jatuh ke api, tetapi kamu meloloskan diri dari tanganku."

3. Status Hadis

Mengatahui status hadis atau kualitas hadis merupakan satu bagian terpenting dari beberapa langkah takhrij hadis. Karena status kualitas suatu hadis akan menentukan kerja

\footnotetext{
${ }^{16}$ Lihat Syuhudi Ismail, metodologi penelitian hadis Nabi (Jakarta: Bulan Bintang, 1992), h. 131.
} 
lanjutan peneliti hadis. Ada tiga kualitas hadis yang telah ditetapkan ulama hadis, ${ }^{17}$ shahih, hasan dan Dha'if. ${ }^{18}$

Bila hadis yang diteliti berkualitas shahih dan hasan, maka suatu hadis perlu dilanjutkan penelitiannya, bagi memastikan kedudukan hukum dan hikmah yang terdapat dalam hadis, jika hadis berkaitan dengan hadis hukum, dan dijadikan hujjah bagi penetepan hukum atau dijadikan petunjuk dalam menjalankan ajaran rasulullah saw.

Bila setelah dilakukan penelitian terhadap suatu hadis, dan ternyata hadisnya berstatus dhai'if, maka hadis yang seperti ini dijadislan sebagai penguat untuk amal-amalan sunnah (fadhail a'mal), dengan ketentuan hadisnya tidak terlalu da'if. ${ }^{19}$

Berikut ini konklusi kualitas hadis yang telah dilakukan pentakhrijannya melalui enam kitab (Kutub Sittah) standar hadis yang telah ditetapkan sebagai acuan, maka hadis:

1. Hadis pertama; yakni hadis nomor 7 bab (XVI) menjaga sunnah-sunnah Nabi saw. Kitab Riyadu Shalihin berkualitas shahih, karena hadis ini diriwayatkan dan terdapat dalam kitab hadis Bukhari, Shahih Bukhari dan juga ditemukan di dalam kitab Muslim, Shahih Muslim, yang menurut ulama hadis dinilai sebagai kitab yang bernilai shahih urutan pertama dan kedua dari enam kitab hadis standar.

2. Hadis kedua: Hadis nomor 8 bab (XVI) menjaga sunnah-sunnah Nabi saw. Kitab Riyadu Shalihin berkualitas shahih, karena hadis ini diriwayatkan dan terdapat dalam kitab hadis Muslim, Shahih Muslim, yang menurut ulama hadis dinilai sebagai kitab yang bernilai shahih urutan kedua dari enam kitab hadis standar.

\section{Pemahaman Ulama Terbadap Hadis Berbahasa Tamsil Tentang Menjaga Sunnah-Sunnah Nabi Saw}

\section{Hadis Pertama}

Hadis yang ditampilkan pada bagian ini merupakan hadis yang terdapat dalam kitab Riyadus Shalihin pada bab ke 16, menjaga sunnah-sunnah Nabi saw. Pada bab tersebut hadis ini belum lengkap sanadnya, setelah melakukan beberapa langkah takhrij hadis ini telah dilengkapi sanadnya.

17 Muhammad al-Maliki, almanhal al-latif fi ushul al-hadis al syarif (Jeddah: Matabi’ Syahr, 1982), h. 5657.

${ }^{18}$ Hadis yang telah memenuhi lima syarat: 1. Sanadnya bersambung, 2. Perawinya 'Adil, 3. Perawinya Dhabt (sangat kuat hapalannya), 4. Tidak syaz, dan 5. Tidak ber- Illat. Sedangkan hadis Hasan adalah hadis yang memiliki semua syarat hadis shahih ini, hanya saja pada syarat ketiga hapalan perawinya berstatu "kuat" saja. Adapun hadis dha'if adalah hadis yang tidak memenuhi beberapa syarat hadis yang tersebut ini secara sempurna. Lihat selengkapnya, Muhammad al-Maliki, Ibid.

19 Penjelasan lengkap tentang hal ini dapat dilihat di Fathur Rahman, Ikhtisar Mushtalah Hadis (Bandung: al-Ma'arif, 1987), h. 200-201. 
Seperti yang telah dijelaskan pada bab III penelitian ini, bahwa hadis ini ditemukan dari kitab shahih Bukhari dan Shahih Muslim, yang mana hadis ini diriwayatkan secara makna, seperti yang terlihat pada perbedaan kecil beberapa kosa kata yang digunakan dalam hadis yang ditemukan dari dua kitab hadis tersebut.

Teks atau matan hadis yang dipilih oleh Nawawi dalam kitab Riyadus Shalibin adalah teks hadis yang lafal atau kosa kata yang digunakan oleh Muslim dalam kitab shahinya. Maka pada bagian ini hadis yang dikutip dan dijelaskan pada bab ini juga memilih teks hadis yang digunkan Nawawi yang dikutip dari Shahih Muslim, hal ini dilakukan, selain alasan sumber yang digunakan Nawawi juga karena alasan melengkapi sanad hadis.

a) Teks hadis

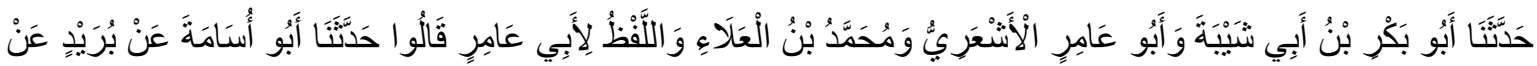

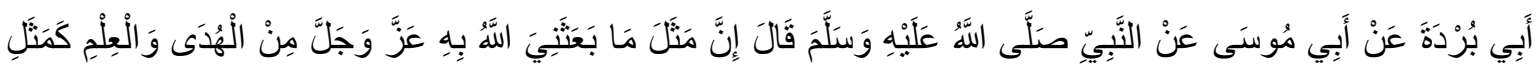

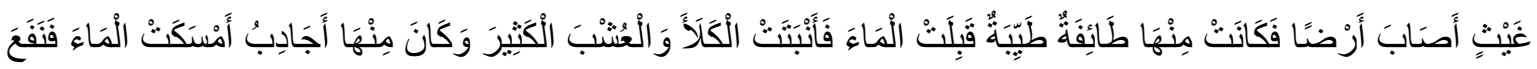

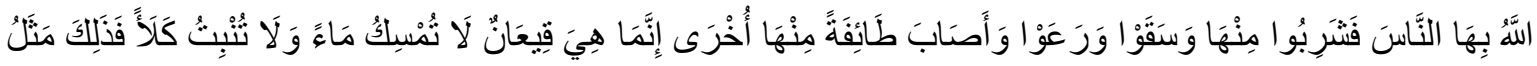

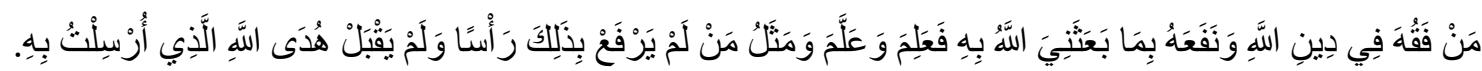
Artinya:

Telah menceritakan kepada kami Abu Bakr bin Abu Syaibah dan Abu 'Amir Al Asy'ari serta Muhammad bin Al 'Alla lafazh ini milik Abu Amir mereka berkata; Telah menceritakan kepada kami Abu Usamah dari Buraid dari Abu Burdah dari Abu Musa dari Nabi saw. beliau bersabda: "Perumpamaan agama yang aku diutus Allah swt. dengannya, yaitu berupa petunjuk dan ilmu ialah bagaikan hujan yang jatuh ke bumi. Diantaranya ada yang jatuh ke tanah subur yang dapat menyerap air, maka tumbuhlah padang rumput yang subur. Diantaranya pula ada yang jatuh ke tanah keras sehingga air tergenang karenanya. Lalu air itu dimanfaatkan orang banyak untuk minum, menyiram kebun dan beternak. Dan ada pula yang jatuh ke tanah tandus, tidak menggenangkan air dan tidak pula menumbuhkan tumbuh-tumbuhan. Seperti itulah perumpamaan orang yang mempelajari agama Allah dan mengambil manfaat dari padanya, belajar dan mengajarkan, dan perumpamaan orang yang tidak mau tahu dan tidak menerima petunjuk Allah yang aku diutus dengannya."

b) Penjelasan hadis

Peneliti mengupayakan penjelasan hadis berbahasa tamsil ini berdasarkan kitab-kitab syarah yang memuat hadis ini secara penuh serta menghususkan kajiannya pada syarah (pemahaman) hadis. 
1) Syarah hadis Shahih Muslim ${ }^{20}$

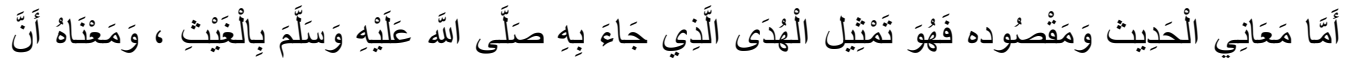

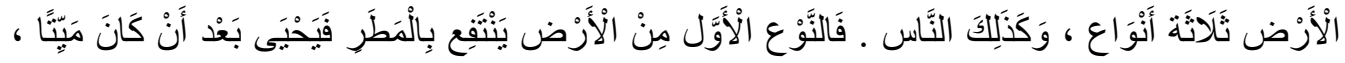

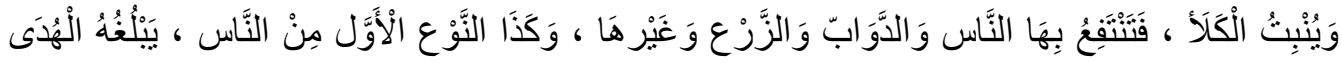

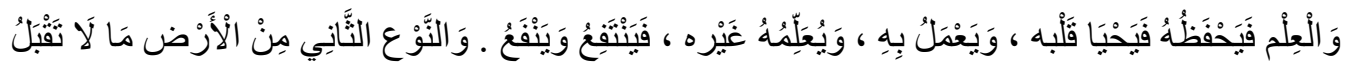

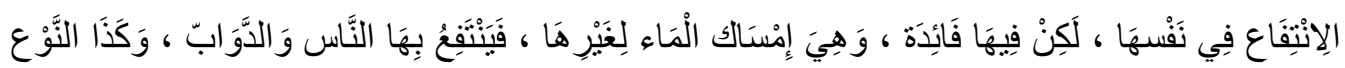

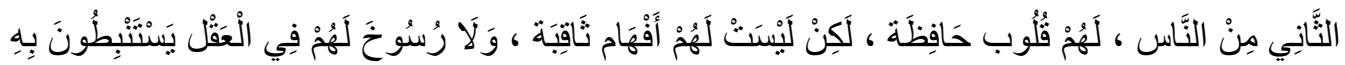

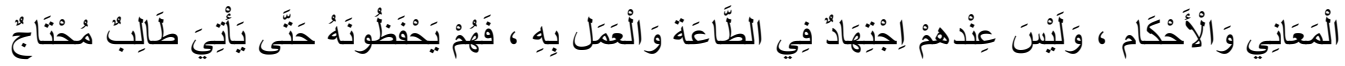

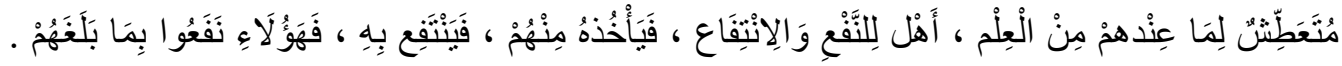

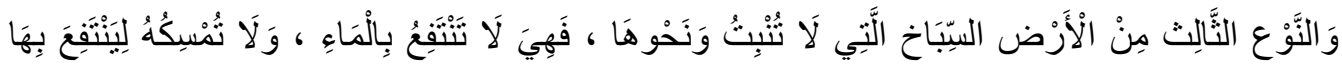

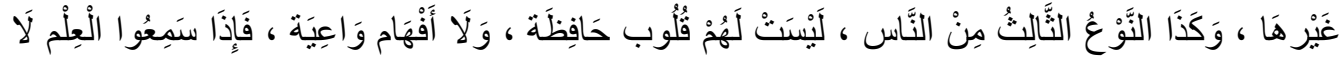

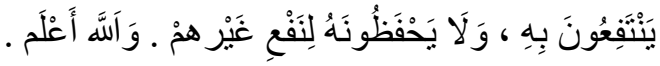

Nabi saw. menggambarkan atau membuat perumpaan melalui hadis ini, berkenaan dengan manusia yang menghadapi petunjuk yang dibawa olehnya (Rasulullah saw) dan ilmu pengetahuan darinya dengan mengumpamakannya dengan tetesan-tetesan air hujan yang menimpa bumi. Adapun keadaan bumi dan atau manusia yang menerima tetesantetesan air hujan dan petunjuk serta ilmu tersebut dibagi atau digambarkan dengan tiga tipe:

Pertama; Ada bagian bumi yang menerima guyuran air hujan dan menumbuhkan rerumputan dan tanam-tanaman lain yang bisa dimanfaatkan oleh manusia, binatang serta tumbuhan. Demikian halnya manusia yang mendapat petunjuk dan ilmu pengetahuan kemudian dijaganya, hatinya menjadi hidup, diamalkan ilmu serta petunjuk yang diperoleh selanjutnya mengajarkan orang lain, hal ini memberikan manfaat baginya maupun bermanfaat untuk orang banyak.

Kedua; Ada bagian bumi yang mampu menampung air yang dimanfaatkan oleh selainya, sekalipun tidak memberikan keuntungan untuk dirinya namun berarti bagi yang lain. Demikian halnya manusia, ada yang memiliki kemampuan menghapal tetapi tidak memahami dengan sempurna apa yang telah dihapalnya, dan tidak ada usaha yang dilakukannya untuk melakukan ketaatan dan pengamalan terhadap apa yang telah dihapal, tetapi pada suatu saat hapalannya disampaikan kepada orang lain yang mampu menggali

${ }^{20}$ Al-Nawawi, shahih Muslim bi syarh al-Nawawi, Juz. 7 (Beirut: Dar ihya' Turas al-'Arabi, 1984), h. 483. 
pengertian terhadap apa yang telah dihapalnya, sehingga orang mendapatkan manfaat terhadap apa yang diperoleh dari hapalannya yang disampaikannya.

Ketiga; selanjutnya adapula bagian bumi yang menerima guyuran hujan yang tidak bisa tumbuh semua jenis tanaman dan rerumputan dan tidak dapat pula menampung air yang bisa dimanfaatkan selainya. Demikianlah halnya manusia, ada yang seakan-akan hatinya tidak mampu menyimpan sekecil apapun petunjuk serta ilmu pengetahuan, demikianpula akalnya tidak dapat menangkap berbagai pengertian, baik untuk kepentingan diri sendiri, apalagi memberikan manfaat bagi orang lain.

Dengan demikian hadis ini merupakan gambaran berupa segmen ilmu pengetahuan dan sekaligus salah satu perumpamaan yang menggambarkan, keutamaan orang berilmu, serta keutamaan belajar dan mengajarkan ilmu pengetahuan, sekaligus anjuran (Targib) yang tegas akan pentingnya mempelajari dan menyebarluaskan ilmu pengetahuan. Hadis ini juga mengancam (tarbib) orang-orang yang mengabaikan ilmu pengetahuan dan petunjuk kebaikan.

2) Syarah Hadis Bukhari ${ }^{21}$

Teks pemahaman hadis yang diperoleh dari buku syarah ditampil apa adanya sesuai dengan penjelasan pensyarah, guna untuk memastikan pemahaman yang ditulis oleh ulama yang berbeda, sekaligus untuk melihat bentuk penjelasan dan perbedaan pengungkapannya.

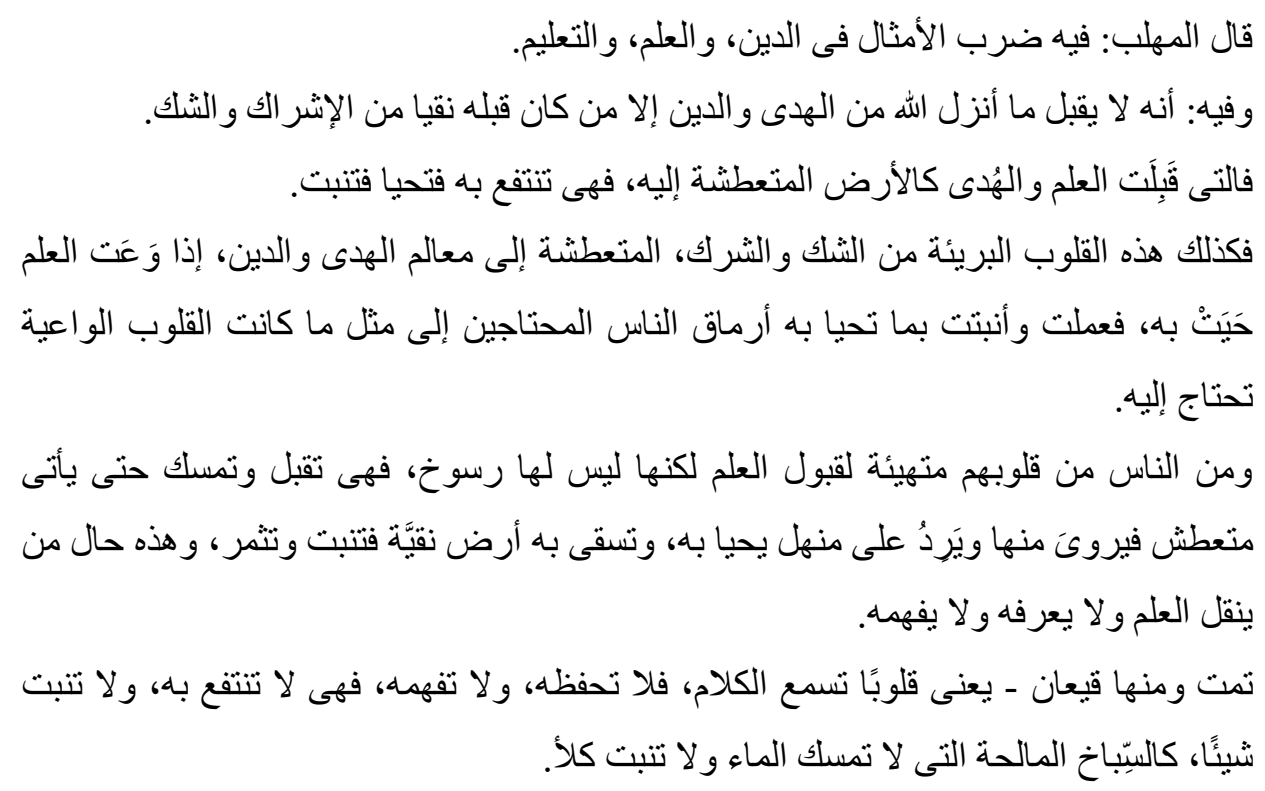

${ }^{21}$ Ibn. Batthal, Syarah Shahih Bukhari, Juz. I (t.t.) 
Ibn. Batthal dalam penjelasan hadis pertama ini, mengawali kutipannya dari seorang ulama yang bernama; Almuhlib, yang menyatakan bahwa hadis ini merupakan perumpamaan terhadap Agama, Ilmu, dan penuntut ilmu.

Berikutnya, Batthal menjelaskan bahwa, petunjuk dari Allah swt. Serta Ajaran-ajaran Agama tidak mungkin diperoleh kecuali oleh orang yang bersih hatinya darisifat kemusyrikan dan keraguan.

Adapun orang yang memperoleh petunjuk dan ilmu pengetahuan diibaratkan dengan bumi yang disirami air kemudian tumbuhlah tetumbuhan, yang mengambil manfaat dari siraman air tersebut dan apa yang tumbuh darinya dimanfaatkan pula oleh yang lain.

Selanjutnya hadis ini menggambarkan, adanya manusia yang memiliki kemampuan menerima petunjuk dan ilmu, tetapi tidak mampu memahaminya secara mendalam, namun dapat disampaikan apa yang telah diterimanya, maka orang yang menerima darinya berkemampuan untuk memahami lebih dari yang menyampaikan kepadanya, inilah ibaran yang menggambarkan bumi yang menampung air hujan yang dimanfaatkan orang lain, namun tidak memberikan manfaat bagi penampungnya.

Terakhir, ada hati yang tidak tersentuh sama sekali dengan petunjuk yang di dengar dan ilmu pengetahuan yang disampaikan, inilah ibarat bumi yang ditimpa air hujan yang tidak dapat ditampung dan tidak pula menumbuhkan apapun tetumbuhan.

Ibn. Batthal, dalam menjelaskan hadis ini dengan penjelasan yang bersifat global atau Ijmaliy. ${ }^{22}$ Sedangkan Nawawi pada penjelasan terdahulu menampilkan penjelasan yang bersifat rinci atau Tahliliy. ${ }^{23}$

\section{Hadis Kedua}

Setelah melakukan langkah takhrij, berupa penelusuran hadis, dari enam kitab hadis standar hadis kedua yang berbahasa tamsil yang terdapat dalam kitab riyadus Shalihin Bab (16) tentang menjaga sunnah-sunnah Nabi saw. Hadis nomor delapan ini, ditemukan hanya dari satu kitab hadis saja, yakni; dari kitab hadis shahih Muslim, lengkap hadisnya berikut ini:

22 Ijmaliy, adalah salah satu metode tafsir al-Qur'an (dan diadopsi oleh pensyarah hadis) yang dalam pelaksanaannya adalah dengan menjelaskan maksud ayat perayat secara garis besar, sesuai urutan penulisan nya dalam mushaf, lihat. Quraish Shihab, Membumikan al-Qur'an (Bandung: Mizan, 1994), h. 85. Dan Abdul Muin Salim, Fiqh Siyasah konsepsi kekuasaan politik dalam al-Qur'an (Jakarta: Raja Grafindo Persada, 2002), hal. 15.

23 Tabliliy adalah salah satu metode tafsir al-Qur'an (dan diadopsi oleh pensyarah hadis) yang dalam pelaksanaannya adalah dengan menjelaskan maksud ayat perayat secara terperinci, sesuai urutan penulisan nya dalam mushaf, lihat. Quraish Shihab, ibid. Dan Muin Salim, loc. Cit. 
a) Teks Hadis

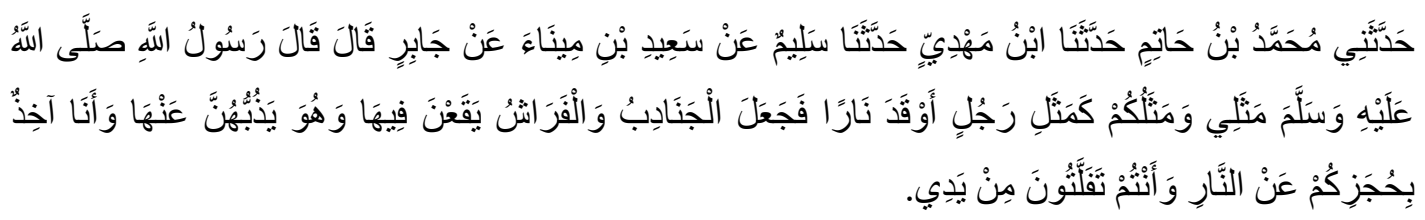

Artinya:

Telah menceritakan kepadaku Muhammad bin Hatim Telah menceritakan kepada kami Ibnu Mahdi Telah menceritakan kepada kami Salim dari Sa'id bin Mina dari Jabir ra. dia berkata; Rasulullah saw. bersabda: "Perumpamaanku dengan kamu sekalian ialah bagaikan seorang yang menyalakan api. Maka serangga-serangga beterbangan menjatuhkan diri ke dalam api itu. Orang tersebut berusaha menarik mereka dengan api dan mereka berusaha mengalahkannya. Dan aku, telah mencegah kamu semua agar tidak jatuh ke api, tetapi kamu meloloskan diri dari tanganku."

b) Penjelasan Hadis

Seorang syaarih, Ibn. Batthal, ketika menjelaskan hadis ini menuliskan seperti berikut ini: ${ }^{24}$

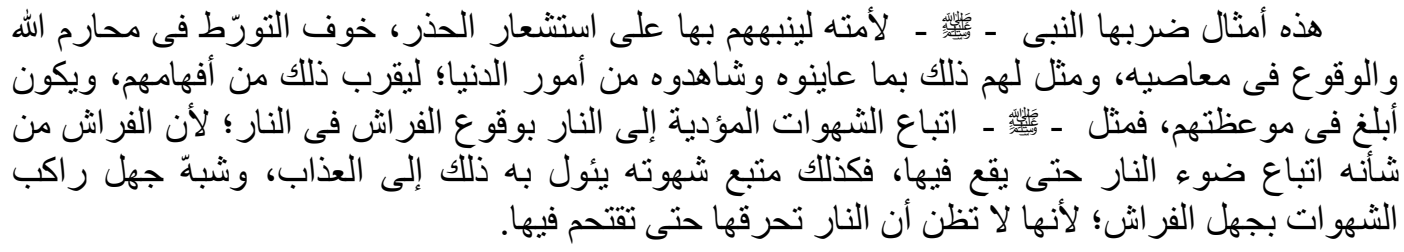

Perumpamaan ini dibuat oleh nabi saw. untuk ummatnya, agar bisa menjadi peringatan bagi mereka untuk berhati-hati untuk tidak terjerumus pada perilaku yang diharamkan Allah swt. dan terjatuh ke lembah maksiat, selanjutnya perumamaan yang disebut nabi saw. Ini untuk umatnya lebih selektif memperhatikan urusan keduniaan agar merekabisa memahami keperluanna akan hal itu, tentu saja perumpamaan ini dibua agar mereka mudah memahami dan menjadkan nasehat ini lebih mengena bagi ummatnya.

Nabi saw, dalam hadis ini memberikan perumpamaan orang yang tidak bisa menguasai nafsu syahawatnya sebagai orang yang menjerumuskan dirinya sendiri ke jurang api neraka, seperti halnya laron-laron yang berebut menjatuhkan dirinya ke dalam nyalaan api, yang menjadi tabiat laron yang nalurinya selalu mendekati cahaya dan menjatuhkan diriya ke sumber cahaya (Api). Demikian halnya para pelaku ma'siat dan pengikut hawa nafsu yang semua itu mengakbatkan pelakunya mendapatkan azab.

${ }^{24}$ In Batthal, op. Cit., Juz. 19, h. 257. 
Mereka para pengikut napsu syahawat dipersamakan sebagai orang bodoh seperti halnya kebodohan laron yang merasa nyaman dengan cahaya dan merasa api tidak akan membakarnya bila mencebur ke dalam api.

Demikian penjelasan ibn. Batthal terhadap bahasa tamsil yang terdapat pada hadis ini. Penjelasan hadis ini ditemukan juga dalam kitab syarah hadis, Fathul Bari, oleh; Ibn Hajar ${ }^{25}$, dia menjelaskan bahasa tamsl yang terdapat pada teks hadis ini dengan maksud:

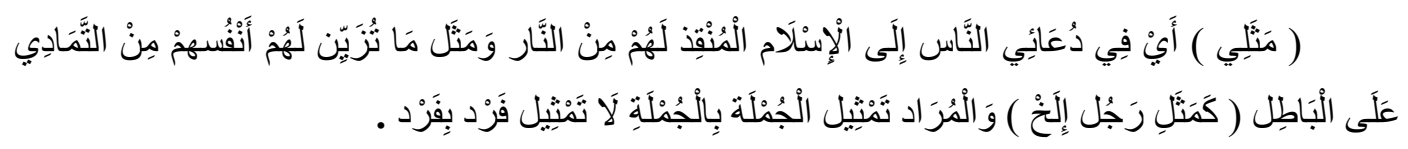

Nabi saw. mengatakan: (perumpamaan diriku), bermaksud, bahwa perumpamaan ajakanku (nabi saw) terhadap manusia untuk meraih Islam yang menyelamatkan mereka dari api neraka, sama halnya (kesungguhannya) mereka menghiasi diri mereka untuk selalu melakukan kemaksiatan. Artinya seakan-akan nabi ingin mengatakan bahwa manusia bersungguh-sungguh menjerusmuskan dirinya ke jurang api neraka, tetapi nabi saw. bersusah payah ingin menyelamatkan mereka agar tidak terjerembab ke dalam neraka.

\section{Hikmah Bahasa Tamsil Hadis}

Hikmah yang peneliti maksudkan pada sub judul ini adalah pelajaran yang dapat dipetik dari hadis yang berbahasa tamsil, yang telah dilakukan pentakhrijannya.

Sudah pasti dua hadis yang menjadi temuan, sekaligus bahan kajian penelitian ini, memuat pelajaran yang sangat banyak, karena ucapan rasulullah saw. Merupakan Jawaami' alkalim. ${ }^{26}$ Artinya sedikit ucapan yang disampaikan nabi saw. bila dipetik hikmahnya akan didapati limpahan hikmah yang dikandung ucapan nabi saw tersebut. Hanya saja untuk kepentingan penelitian ini serta kemampuan peneliti menangkap hikmah dari hadis ini tentu tidak mampu menangkap seluas hikmah yang dikandung oleh hadis seperti ungkapan nabi sebagai "jawami" kalim” maka peneliti hanya mengupayakan hikmah yang tertuang secara teks, konteks, serta pemahaman hadis yang telah diterangkan ulama-ulama yang telah dikutip

${ }^{25}$ Ibn. Hajar, Fathul Bari, Juz. X (t.t), h. 224.

26 "Jawaami' kalim" merupakan istilah yang bersumber dari sabda nabi saw. yang diriwayatkan oleh Abu Hurairah ra. Dia berkata, akau mendengar rasulullah saw. Bersabda: “ saya diutus (oleh Allah) dengan (kemampuan untuk menyatakan) ungkapan -ungkapan yang singkat, namun padat makna...

\section{عن أبي هريرة رضي الله عنه : أن رسول الله صلى الله عليه و سلم قال ( بعثت بجوامع الكلم...}

Lihat Bukhari, Shahih Bukhari, Juz. III (Beirut: Dar Ibn. Kasir, 1987), h. 1087, dan Arifuddin Ahmad, Paradigma Baru Memahami Hadis Nabi Refleksi Pemikiran Pembaruan Prof. Dr. Mubammad Syubudi Ismail (Ciputat: MSCC, 2005), h. 147. 
penjelasnnya dari beberapa kitab syarah yang menjelaskan hadis-hadis dalam penelitian ini saja, antara lain:

1. Pelajaran yang dimuat oleh hadis pertama;

a. Hadis ini merupakan hadis yang menjelaskan anjuran mengikuti sunnah nabi saw. berkaitan dengan menutut ilmu dan mengupayakan untuk meraih petunjuk yang disampaikannya.

b. Kebersihan jiwa merupakan syarat utama yang mest dimiliki setiap orang, agar mendapatkan ilmu dan mejalankan petunjuk.

c. Ada tiga tipe manusia ketika berhadapan dengan ilmu dan petunjuk rasul saw: pertama; tipe orang yang mampu memahami untuk diamalkan serta disebarluaskan, kedua; tipe orang yang hanya bisa menerima tetapi tidak bisa memahami serta memaksimalkan pengamalannya secara pribadi, namun dapat menceritakankan apa yang telah didengarkan, ketiga; tipe orang yang tidak bisa mencerna ilmu dan petunjuk untuk keperluan pribadi, apalagi memberikan pencerahan kepada orang lain.

d. Hadis ini menjelaskan salah satu fungsi kenabiannya, yakni sebagai pendidik dan pada saat yang sama menjadi tuntunan bagi yang berprofesi sebagai pendidik untuk meneladani nabi saw. dalam hal salah satu metode pendidikan, yakni memberikan keteladanan dalam hal menyederhanakan pembahasan agar memudahkan kepahaman peserta didik. Dalam hadis ini digambarkan dengan cara penggunaan bahasa tamsil (perumpamaan) atau dalam bahasa yang sederhana mempermudah pemahaman peserta didik dengan memberikan contoh kasus, berupa cerita, kisah, bahkan dengan penghargaan serta hukuman yang tidak membahayakan.

e. Hadis ini juga menjelaskan bahwa profesi sebagai pendidik merupakan profesi yang mulia.

Inilah sebagian kecil dari pelajaran yang dapat dikutip dari hadis ini.

2. Pelajaran yang dimuat oleh hadis kedua, antara lain;

a. Perumpaan yang dimuat hadis ini, menggambarkan kepedulian Rasulullah kepada ummatnya.

b. Kecenderungan manusia akan kemilaun duniawi pada umumnya terlalu berlebihan, sehingga lupa akan bahaya yang menghadang.

c. Keteladanan nabi sebagai seorang pendidik yang santun dan tawaduk, tergambar pada perilaku dan ucapan.

d. Profesi sebagai pendidik semestinya memberikan keteladanan dalam bertuturkata kepada peserta didik, dengan tutur kata yang menyejukkan. 
e. Seorang pendidik harus memahami bahwa ada diantara peserta didik yang tidak menyadari akan perilaku yang membayakannya, yang semestinya selalu diperingatkan oleh seorang pendidik.

Demikian pelajaran singkat yang tergambar dari pemahaman ulama dari hadis ini, petunjuk dari teks serta konteks hadis dan posisi hadis pada kitab standar.

\section{PENUTUP}

Bahasa Tamsil merupakan suatu ungkapan bahasa yang berbentuk "perumpamaan" atau mempersamakan sesuatu dengan sesuatu yang lain. Dalam Bahasa Indonesia biasa disebut dengan "pribahasa"; hanya saja jika bahasa pribahasa selalunya singkat dan populer, dan membandingkan satu hal dengan satu hal yang lain. Sedangkan bahasa tamsil dalam hadis, seperti halnya bahasa tamsil (al-masal) al-Qur'an, tidak hanya mempersamakan sesuatu dengan sesuatu yang lain secara ekual, tetapi persamaannya selalu lebih banyak.

Demikian halnya bahasa tamsil yang ditemukan dalam kitab hadis Riyadush Shalih yang disusun oleh imam Nawawi, pada bab menjaga sunnah-sunnah nabi saw. Menunjukakan bahwa bahasa tamsil, tidak hanya mempersamakan sesuatu dengan sesuatu secara ekual, tetapi mempersamakan sesuatu dengan banyak hal.

Dalam bab menjaga sunnah-sunnah Nabi saw., kitab Riyadhu Shalihin ditemukan dua hadis yang berbahasa tamsil, hadis-hadis dimaksud ditelusuri dari enam kitab hadis standar atau kutub sittah;

Pertama; hadis yang diriwayatkan oleh Bukhari dan Muslim, Bukhari menempatkan hadis dimaksud pada kitab shahihnya Juz I, hadis yang ditakhrij ini ditemukan satu riwayat pada kitab Ilmu (Kitab III) bab (20) keutamaan orang yang berilmu dan mengajarkan ilmu hadis no. 79. Sedangkan Muslim menempatkan hadis ini Pada kitab shahihnya Juz IV, hadis ini ditemukan satu riwayat pada kitab (43) keutamaan (الفضائل) bab (V) باب بيان مثل ما (keutamaan umat nabi Muhammad saw. yang berilmu dan mendapatkan hidayah بعث النبي صلى الله عليه و سلم من الهدى و العلم hadis no. 1787,

Kedua; Hadis yang diriwayatkan oleh Muslim ditemukan pada Pada kitab shahihnya Juz IV, hadis ini ditemukan satu riwayat pada kitab (43) keutamaan (الفضائل) bab (V) باب بيان مثل ما (keutamaan umat nabi Muhammad saw. yang berilmu dan mendapatkan hidayah بعث النبي صلى الله عليه و سلم من الهدى و العلم hadis no. 1787.

Nawawi, penyusun kitab riyadhu Shalihin, menampilkan kedua hadis yang berbahasa tamsil dalam kitabnya, dengan menggunakan teks hadis yang diriwayatkan Muslim. 
Hadis-hadis yang berbahasa tamsil dalam bab menjaga sunnah-sunnah Nabi saw, kitab hadis Riyadush Shalihin, berkualitas Shahih. Hadis-hadis ini oleh ulama difahami sebagai, (a). hadis targib (pengajaran yang berisi dorongan positif), (b). hadis tarbib (pengajaran yang berisi peringatan), dan (c). Pembalajaran dari nabi saw. untuk ummatnya agar menjadi pelopor dalam melakukan kebaikan sehingga selalu menebarkan manfaat kepada orang lain dimana dan kapan saja.

\section{REFERENSI}

\section{Al-Qur'an al-Karim}

Departemen Agama RI. Al-Qur'an dan terjemabnya Surabaya: Fajar Mulia. 2009.

'Abd. al-Hay al-Farmawi. Bidayah fi Tafsir Al- yMaudu'iy: Dirasah Manhaji'ah. terj. Suryan A. Jamarah. Metode Tafsir Maudu'i: Sebuah Pengantar Jakarta: Raja Grafindo Persada. 1996.

Abdul Muin Salim. Figh Siyasah konsepsi kekuasaan politik dalam al-Qur'an Jakarta: Raja Grafindo Persada. 2002.

Abustani Ilyas dan La Ode Isma’il Ahmad. Filsafat Ilmu Hadis Surakarta: Zada Haniva. 2011.

Abu Zakaria Yahya bin Syaraf al-Nawawi. Riyadhus al-Shalihin. terj. Jakarta: Pustaka Amani. 1999. . Shabih Muslim bi syarh al-Nawawi. Beirut: Dar ihya' Turas al-'Arabi. 1984.

Ahmad bin Hambal. Musnad Abmad. Mesir: Wazir al-auqaf. t. d.

Ahmad Syadzali dan Ahmad Rofi'i. Ulumul Qur'an I Bandung: Pustaka setia. t. d.

Atabik Ali dan A. Zuhdi Muhdlor. Kamus Kontemporer Arab Indonesia. t.d.

Ahmad Warson Munawwir. Kamus al-Munawnir: Arab-Indonesia Terlengkap Surabaya: Pustaka Progresif.1997.

Abū al-Husain Ahmad Ibn Fāris Ibn Zakariyā selanjutnya ditulis Ibn Zakariya. Mu'jam Maqāyìs al-Lugab Beirūt: Dār al-Fikr. 1979.

Arifuddin Ahmad. Paradigma Baru Memahami Hadis Nabi Refleksi pemikiran Pembaharuan Mubammad Syubudi Ismail jakarta : MSCC. 2005.

Arief Halim. Metodologi Tahqiq Hadith Secara Mudah dan Munasabah Malaysia: Universiti Sains Malaysia. 2007.

Fathur Rahman. Ikhtisar Mushtalah Hadis Bandung: al-Ma'arif. 1987. 
Fungsi Perumpamaan dalam al-Qur'an. Jurnal Tarbawiyyah Vol. 10 no. 2 edisi Juli-Desember 2013.

Ibn. Batthal. Syarah Shabih Bukhari. t.d.

Ibn. Hajar. Fathul Bari. t.d.

Jujun Suriasumantri. "Penelitian Ilmiah. Kefilsafatan dan Keagamaan: Mencari Paradigma Kebersamaan". dalam Mastuhu dkk. Tradisi Penelitian Agama Islam. Bandung: Nuansa. 1998.

Komaruddin Hidayat. Memahami Bahasa Agama Sebuah Kajian Hermeneutika Bandung: Mizan. 2011.

Lexy J. Moleong. Metodologi Penelitian Kualitatif. Bandung: Remaja Rosdakarya. 2008.

Al-Khatib. Muhammad 'Ajjaj. al-Sunnah Qabl al-Tadwin Bairut: Dar al-fikr. 1997.

Mahmud al-Tahhan. Taisìr Mustalah al-Hadìs Beirūt: Dār al-Fikr. t.t.

. Usul al-Takbrij wa Dirasat al-Asanid Riyad: Maktabah al-Ma'arif li al-Nasyr wa alTauzi‘. 1996.

Manna al-Qaththan. Mababits fi Ulumil Qur'an Mesir: Maktabah Wahbah. 1992.

Muhammad Ibn Ya'qūb al-Fairūz Ābādi. al-Qāmùs al-Mubìt Beirūt: Mu'assasah al-Risālah. 2005.

Muslim bin al-Hajjaj. Shabih Muslim. Beirut: Dar. Ihya' al-Turas al-'Araby. t.th.

Muhammad bin Isma’il al-Bukhari. Sabih Bukhari. Beirut: Dar. Ibn. Kasir. 1987.

M. Quraish Shihab. Membumikan al-Qur'an. Bandung: Mizan.1992.

Tafsir al-Mishbah Pesan. Kesan. dan Keserasian al-Qur'an. Jakarta: Lentera Hati. 2006.

Muhammad al-Maliki. almanhal al-latif fi ushul al-hadis al syarif. Jeddah: Matabi' Syahr. 1982.

Munawwir. AW. Kamus al-Munawnir Arab-Indonesia Terlengkap Yogyakarta: Pustaka Progressif. 2002

Noeng Muhadjir. Metodologi Penelitian Kualitatif. Yogyakarta: Rake Sarasin. 1998.

Sa ‘̄ìd Ibn Abdullāh ‘Āli Hamīd. Turuq Takhrìj al-Hadìs Riyad: Dār 'Ulūm al-Sunnah. 2000.

al-Suyuti. al-Itqan fii Ulum al-Qur'an. t.d.

Syuhudi Ismail. Metodologi Penelitian Hadis Nabi. Jakarta: Bulan Bintang. 1992.

Zulfahmi Alwi. Reproduksi Manusia Suatu Kajian Hadis dan Hukum Yogyakarta: Cakrawala Publishing. 2009. 